\title{
Chapter II.7
}

\section{THE GYPSUM KARST of ITALY \\ Paolo Forti \& Ugo Sauro}

\section{Introduction}

Gypsum karst has been studied in Italy since the last decades of the 19th Century. In 1917 the geographer Olinto Marinelli published "Fenomeni carsici delle regioni gessose d'Italia", a fundamental synthesis of the early research. He distinguished 56 different morpho-karstic gypsum units and/or areas, which are all different in size and character (Fig.1), and described them, paying special attention to their surface morphology and hydrology. Marinelli listed all the main gypsum units and only a few secondary outcrops were overlooked.

After Marinelli's synthesis, except for some discussion of archaeological caves, only a few papers about gypsum karst and environment were published until the nineteen-fifties. In the nineteen-sixties and seventies much exploratory work and documentation was carried out in the Emilia Romagna area, principally devoted to the gypsum caves, and undertaken by the local speleological clubs and university researchers (Bertolani \& Rossi, 1972a, 1972b; Gruppo Speleologico Emiliano et al, 1966, 1972).

An important milestone in the history of knowledge about the gypsum karst of Italy was the International Symposium on Evaporite Karst held in Bologna and Palermo during 1985 (P. Forti \& P. Grimandi [Eds], 1986; P. Forti, V. Agnesi, T. Macaluso, M. Panzica La Manna [Eds], 1987). This symposium enhanced gypsum karst research in Italy and encouraged exploratory work by the speleological clubs. Two main inter-disciplinary research projects on gypsum karst morpho-units have subsequently been undertaken (P. Forti, V. Agnesi, T. Macaluso [Eds], 1989; G. Ferrini [Ed], 1997).

The chapters that describe gypsum karst surface landforms in this publication contain many references to examples of gypsum karst in Italy, and these supplement the descriptions provided below.

\section{The geographical and geological framework of gypsum karst in Italy}

The largest gypsum formation outcrops are those in Sicily, with a total outcrop area of more than $1,000 \mathrm{~km}^{2}$ (Forti et al, 1987). Emilia Romagna follows, with outcrops totalling little more than $100 \mathrm{~km}^{2}$ (Bassi et al, 1989; Casali et al, 1983; Costa et al, 1994). The numbers of surveyed caves in these regions are about 200 and more than 500 respectively. In the Alps the best known area of gypsum is that of Colle del Piccolo Moncenisio, with an extent of several $\mathrm{km}^{2}$. Otherwise, the more extensive gypsum "outcrops" are within submarine "closed basins" on the floor of the Mediterranean, and details of their geomorphology are only poorly known.

From the geographical viewpoint Italy's gypsum karst areas have developed across a wide range of latitudes, altitudes and morpho-climatic zones. They extend between latitudes $37^{\circ}$ and $47^{\circ} \mathrm{N}$ and altitudes from sea level to more than 2,700m a.s.l. in the Alps. Gypsum karst areas occur 


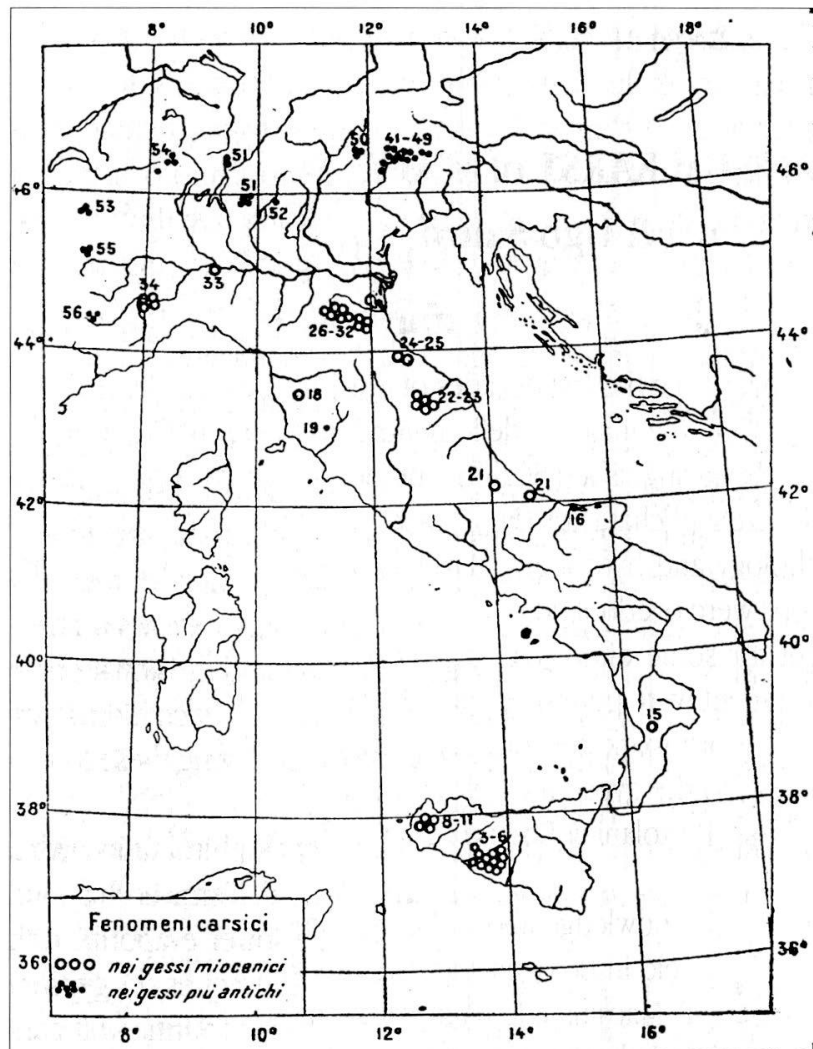

Fig. 1 - The morpho-karstic gypsum units and/or areas of Italy according to the figure published by $\mathrm{O}$. Marinelli in 1917. Marinelli identified all the main gypsum units.

in fold belts associated with the Alpine Orogeny and also in marginal areas (Sardinia). The climates vary between humid middle latitude mountain types and semi-arid Mediterranean types.

From the stratigraphical viewpoint three main groups, or complexes, of gypsiferous rock formations can be distinguished: a Palaeozoic complex, an early Mesozoic complex, and a late Neogene complex (Desio, 1973).

The Palaeozoic evaporites are a typical transgressive sequence, known as the Formazione a Bellerophon, that was deposited in a semi-arid coastal lagoonal environment during the Late Permian. It consists of a series of cycles, each cycle starting with grey dolomite and clay, and ending with beds of gypsum. The formation is up to $400 \mathrm{~m}$ thick, and it crops out on valley sides in the Southern Alps, near Friuli, Veneto and Trentino.

The Mesozoic complex, comprising a sequence of Late Triassic age, is recognized in the western Alps, around the border between Italy and France, in the Northern and Adriatic Apennines, and in Sardinia.

The Neogene complex is more significant. Of late Miocene (Messinian) age, it is called the Formazione Gessoso Solfifera, and is recognizable at surface outcrop and in buried successions throughout most of the peninsular, from the Northern Apennines to Sicily. This complex is the product of a highly significant palaeogeographical event that occurred between 6.5 and 5 million 
years ago, when the Mediterranean basin became closed, losing its connection with the Atlantic Ocean. The isolated Mediterranean sea shrank, leaving several salt lakes nested inside cryptodepressions nearly two thousand meters below the original sea level. In these over-saturated lakes great volumes of salts were precipitated, contributing to thick evaporite formations made up mainly of gypsum and rock salt. During the late Miocene, Pliocene and Quaternary these formations were partly affected by the Alpine Orogeny, and have become part of the tectonic fabric of the Italian peninsula.

In the Northern Apennines the Formazione Gessoso Solfifera outcrop is effectively homoclinal, dipping towards the Po Plain. Starting from the base, the formation includes bituminous clayey marls, evaporitic limestone, and thick layers of gypsum with thin marly intercalations, for a total thickness of about $150 \mathrm{~m}$. The underlying rock unit is the Formazione Marnoso-arenacea romagnola, a flysch-like complex of Tortonian to Langhian age, with a total thickness that ranges between 4,000 and $5,000 \mathrm{~m}$. The overlying Formazione a Colombacci, comprises clayey and silty marls with intercalations of evaporitic limestone lenses. This formation locally shows a sharp angular unconformity at its base, the expression of a deformational episode and erosional phase that occurred at the end of the Messinian. A latest Messinian vertebrate fauna has been discovered within palaeokarst features just below this discontinuity (Costa et al, 1986). Overlying these formations are transgressive clayey and sandy beds of Pliocene age.

In Sicily the Formazione gessoso solfifera comprises two main lithostratigraphical units with a maximum thickness of $1500 \mathrm{~m}$, underlain by a siliciclastic unit (Formazione di Terravecchia) and covered by clayey marls (Trubi) and clay. From the bottom to the top the lower evaporitic unit consists of: a) diatomite and diatomaceous marls (tripoli), b) evaporitic limestones, c) gypsum with intercalations of gypsiferous marl, d) salts (mostly chlorides). The upper evaporitic unit consists of: a) cycles of gypsum and gypsiferous limestones with sandy and clayey layers, b) bioclastic limestones changing laterally and upwards into gypsum, c) clayey sands (arenazzolo).

In western Sicily there are commonly sulphur mineral ores within and at the base of the microcrystalline gypsum beds.

In some parts of Sicily and Calabria the gypsiferous formation is cut by an erosion surface and is buried with angular unconformity by clastic sediments, such as calcarenites or transgressive conglomerates, and unconsolidated coastal and fluvial sediments.

\section{Main types of morpho-structures}

From the morpho-structural standpoint the main gypsum morpho-units comprise tabular blocks, of plateau and mesa type, homoclinal ridges of cuesta type, dome-like hills, outliers sitting on older clastic formations, bands along some major slopes contained within multiple folds, and tectonic slices inside complex structures.

The most distinctive, and the largest, morpho-structure within the Italian peninsula is a homoclinal ridge, locally displaying bevelled cuesta topography and cut by many water gaps. This structure, called the Vena del gesso, extends across the Northern Apennines between Bologna and the Adriatic Sea,and its main sector is $25 \mathrm{~km}$ long, but very narrow. 
In Sicily there are many large- and medium-sized morpho-structures, some displaying the characteristics of tectonic wedge plateaux (for instance the Santa Ninfa Plateau), or of tabular plateaux (such as Serra Ciminna), or homoclinal ridges (like Serra Balate).

\section{The surface forms}

In some areas the gypsum outcrops are almost completely covered by soil and vegetation, though elsewhere rocky surfaces dominate. Thus, gypsum pavements, with typical weathering aspects and karren forms, are exposed at some localities.

There are some typical blind valleys in the gypsum karst of the Northern Apennines and in Sicily. In the Northern Apennines the Rio Stella - Rio Basino creek valley, more than $1.5 \mathrm{~km}$ long, is developed in clayey marls and ends against the high rocky bluff of Vena del gesso, in macrocrystalline gypsum, where a ponor swallows the waters (there is also a $1.5 \mathrm{~km}$-long cave system crossing the ridge ). In Sicily the best known blind valleys are developed mostly within gypsum or in clayey marls that overlie gypsum. Examples are the blind valleys of the Biviere creek in the gypsum plateau of Santa Ninfa, about $2.5 \mathrm{~km}$ long, and Lo Sfondato north of Porto Empedocle. All the related ponors feed active cave systems.

A wide variety of sizes and aspects of dolines are present. There are populations of very small dolines (1.5-6m in diameter and 0.2-1.5m deep), as in the Dolomites (Bini, 1983) and the western Alps (Capello, 1955). There are also groups of very large dolines, with diameters of several hundred metres, as in the Vena del gesso area. Many intermediate forms between blind valleys and dolines also exist, especially in the gypsum karst of Sicily. From the morphological point of view, there are funnel-shaped and pit-like dolines, bowl- and plate-shaped dolines, nearly symmetrical plateau dolines, and asymmetrical slope dolines.

The large variety of dolines recognized in some gypsum areas is underlined by the classification suggested by Capello (1955), for the high mountain gypsum karst of Moncenisio in the western Alps. Capello distinguished the following types: a) symmetrical funnel-shaped dolines, b) symmetrical flat-bottomed dolines (or saucer-shaped dolines), c) asymmetrical dolines, d) bowlshaped dolines, e) pit dolines, f) pits, g) corridors derived from the fusion of several dolines. In type e) both typical cylindrical dolines and half-funnel dolines swallowing small rivulets are included. The sizes of these dolines range from a few to more than $100 \mathrm{~m}$ in diameter and from a few to more than $20 \mathrm{~m}$ in depth (Fig. 2).

There are also polje-like landforms that, from the hydrological point of view, are normally open but represent "ponors". They are relatively common in Sicily (such as il Pantano, to the west of Siculiana Mare). In the Alps a glaciokarstic polje, the polje of La Valoire, was described by Nicod (1976).

\section{Surface landforms in rocks overlying gypsum}

Some closed depressions develop by subsidence and collapse within non-karstifiable rocks that overlie gypsum.

In Italy doline-like forms and large, but shallow, closed basins, are both present. In Sicily there 


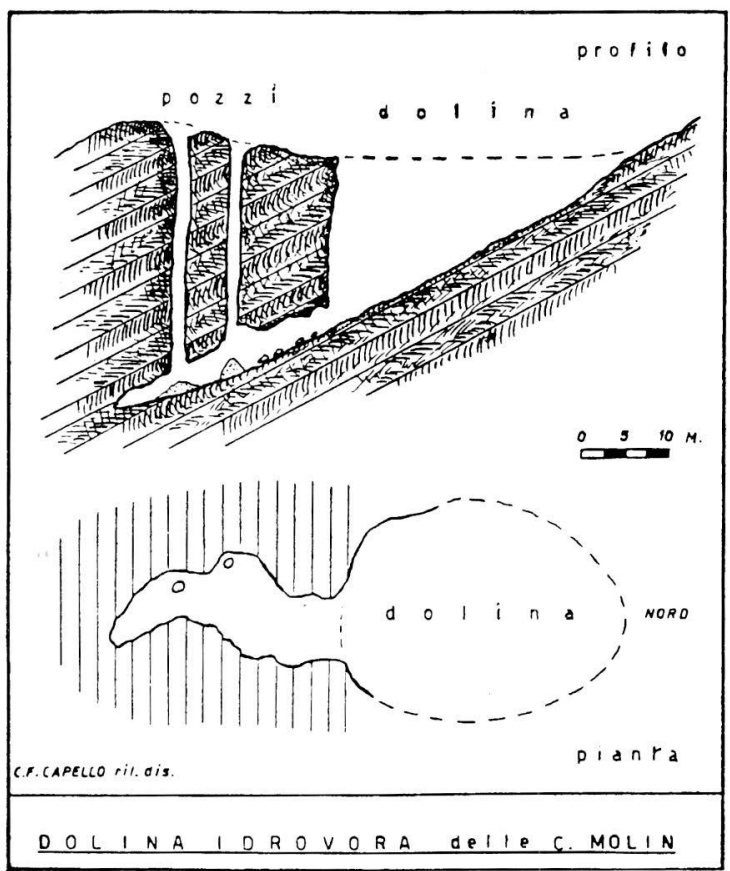

Fig. 2 - Cross-section of a complex landform in the gypsum karst of the alpine area of Moncenisio (After Capello, 1955).

are many large depressions that are normally occupied by lakes, with surface areas ranging from a few hundred $\mathrm{m}^{2}$ to about $2 \mathrm{~km}^{2}$. The Pergusa lake, near Enna (Sicily), has a surface area of $1.83 \mathrm{~km}^{2}$ and a maximum depth of only $4.6 \mathrm{~m}$. In the Alps there are both subsidence dolines and collapse dolines. In the Moncenisio area two new collapse dolines opened during the summer of 1965 (Nicod, 1976), and in the Agordo Valley (in the Dolomites) many new subsidence and collapse dolines have formed during the last few decades. In the braided bed of the Tagliamento River, in the Southern Alps, many collapse phenomena have occurred during this century (about 10 during the decade 1955-1964 according to Gortani, 1965). Other collapse phenomena are described in the urban area of Gissi in Southern Abruzzo (Burri, 1986).

\section{Hydrological aspects and caves}

In the gypsum karst of Italy the only areas carefully surveyed by speleologists are the Vena del gesso in the Northern Apennines, the Verzino plateau area in Calabria and the Santa Ninfa plateau in Sicily. Most areas still await investigation and it is inevitable that many more caves will be discovered in the future.

Nevertheless, Italy hosts some of the world's deepest and more complex gypsum caves. This reflects both Italy's Mediterranean climate, which supplies large volumes of water seasonally to the deep circulation systems, and the presence of thick and highly tectonized gypsum sequences. These conditions support development of extensive and deep caves during relatively short timescales.

From the hydrogeological viewpoint hardly any of Italy's gypsum caves appear to owe their 
genesis to lateral or basal injection. Nearly all of them seem to be normal seepage caves, developed entirely within the percolation zone. In fact, they are generally the expression of hydrogeological systems with a very low level of hierarchy. They show a very simple hydrological structure that may be viewed schematically as comprising a main, sub-horizontal, drainage tube following the piezometric surface, with only a few, or without any, small secondary tributaries. Connections with higher inlet points are always represented by vertical pits. No truly phreatic structure can exist in this type of cave. In those caves that show evidence of several superimposed levels the structure is related to sequential steps in the lowering of local base level.

In the Vena del gesso nearly 500 caves have been explored and mapped, and nearly 100 important hydrogeological systems have been identified (Badini, 1967; Bertolani et al, 1980). In Sicily there are nearly 200 known caves, and only a few in Calabria. From the point of view of their interactions with surface hydrology, it is possible to distinguish the following types of cave:

a) hydrogeological through caves, that lead from a sink point at the closure of a blind valley or in the floor of a large doline and terminate as spring caves; these caves are normally multi-level systems;

b) sink caves, that are similar to the previous type but do not present explored connections through to spring systems;

c) spring caves, that are also similar to type a) but do not present explored connections back to sink systems;

d) active caves with streams flowing underground but having no explored connection to either sink or spring systems;

e) relict inactive caves, currently dry and lacking connections to an active hydrological network;

f) tunnels formed as "hypogean meanders", developed laterally as loops from valley floors and consisting of sink caves, twisting active underground passages and cave-springs (Chiesi, 1989).

Some of the more important surveyed caves are listed in table 1.

There are also many small tectonic caves and some vertical systems developed in gypsum. The deepest shaft so far described is the "Pozzo A", near the mountain refuge of Moncenisio, which is more than 200m deep (Dainelli, 1908; Capello, 1955). There is no up-to-date information about the state of this shaft, or that of the Grotta Gianset, over 100m deep, which is not far from the first. Their current condition may depend upon a variety of unique factors that affect each individual high mountain shaft, as in general they will all undergo a very fast evolution (several metres, if not tens of metres, per year), precluding the possibility of their existence extending over long periods.

From the point of view of the geomorphology of the subterranean cavities the following types can be distinguished:

m) tunnels resulting from "horizontal erosion", and/or from the fusion of several sub-horizontal tubes;

n) pseudo-galleries, resulting from the fusion of several cavities, most commonly formed by vertical percolation along fissures;

o) cylindrical and "ogival" (arch-shaped) pits and cavities;

p) waterfall pits, locally with potholes, 
Table

SOME OF THE MAIN GYPSUM CAVE SYSTEMS OF ITALY

\begin{tabular}{|l|c|c|c|c|r|r|}
\hline Name & region & rock age & type & $\begin{array}{l}\text { number } \\
\text { of levels }\end{array}$ & length $(\mathrm{m})$ & depth(m) \\
\hline Spipola-Acquafredda & ER & M & a & 4 & 10.400 & 110 \\
\hline Ingh. SW di Ca' Siepe & ER & M & b & 3 & 2500 & 205 \\
\hline Re Tiberio" & ER & M & c & 3 & 2110 & 75 \\
\hline Tre Anelli" & ER & M & b & 3 & 1074 & 144 \\
\hline Abisso 50" & ER & M & b & 2 & 1200 & 149 \\
\hline Rio Stella-Rio Basino• & ER & M & a & + & 1500 & 100 \\
\hline F10+• & ER & M & b & & 1450 & 210 \\
\hline Grave Grubbo * & CA & M & d & & 1470 & 48 \\
\hline Grotta dello Stige* & CA & M & c & & 575 & 21 \\
\hline S. Ninfa & SI & M & c & + & 1350 & 25 \\
\hline M. Conca ${ }^{\circ}$ & SI & M & b & & 500 & 90 \\
\hline M. Conca $^{\circ}$ & SI & M & c & & 250 & 40 \\
\hline Tanone della Gaggiolina & ER & T & f & & 420 & 40 \\
\hline & & & & & & \\
\hline
\end{tabular}

Key: Region - ER = Emilia e Romagna, CA = Calabria, SI = Sicily

Gypsum age $-\mathrm{M}=$ Messinian, $\mathrm{T}=$ Triassic

Type - see the types described above

the caves indicated with the same symbols as: ", $\bullet, *,{ }^{\circ}$, are part of the same active system.

q) collapse chambers;

r) cavities formed due to slope tectonics.

A very common feature is the "pseudo-phreatic tube", which is similar in appearance to a normal phreatic conduit but develops starting from tunnels that are almost completely filled by sediments, and so has its roof and walls in gypsum and its floor in sediment. If the sediments are eroded typical galleries with ceiling half tubes result.

Within the main drainage tubes of some active caves in gypsum the presence of suspended material in the water has been demonstrated as being by far the main influence upon the enlargement of some active cave passages. On average mechanical erosion represents over $60 \%$ of the overall mass wasting of the cave walls. Condensation dissolution is the second most important effect (about 30\%), and normal dissolution is by far the least active process in this situation. In the Grave Grubbo Cave, over $1 \mathrm{~cm}$ of riverbed lowering was measured by means of M.E.M during a single 28-hour flood.

Chemical deposits are scarce in Italian gypsum caves, but they are generally more common than in other climatic areas of the world. Most recorded examples are of calcite speleothems, but gypsum speleothems are found in the south of Italy. Only a few gypsum karst areas in Italy have been studied with specific regard to their chemical deposits, but they are the only ones in the world where such detailed mineralogical work has been carried out. For this reason, over $90 \%$ of all the world's secondary cave minerals described from gypsum caves to date were detected in Italy.

From the hydrodynamic viewpoint, it is clear that during flood conditions solvent water in the active karst systems flows rapidly $(20-40 \mathrm{~cm} / \mathrm{sec}$ ) and is heavily loaded with suspended material. In the underground galleries erosionally and depositionally significant episodes both occur frequen- 
tly. Generally the water can keep the main passages open, even where there is a significant supply of clastic material.

\section{Types of karst}

A wide variety of karst types can be distinguished according to their geological and geomorphological evolution (see chapter 1.4). In general, the stratigraphical settings are such that the main evaporitic complexes were originally confined by adjacent impervious formations, that preserved them from contact with underground water. However, episodes of deformation and the morpho-dynamic development have allowed the water to penetrate, allowing karstification to begin in deep-seatedsituations.

Undoubtedly the most important gypsum karst setting in Italy is deep-seated karst, both in submarine and terrestrial environments. The many closed subsidence depressions in Sicily, some of which are occupied by lakes, are probably related to lateral water injection into deep-seated gypsum karst from adjacent aquifers.

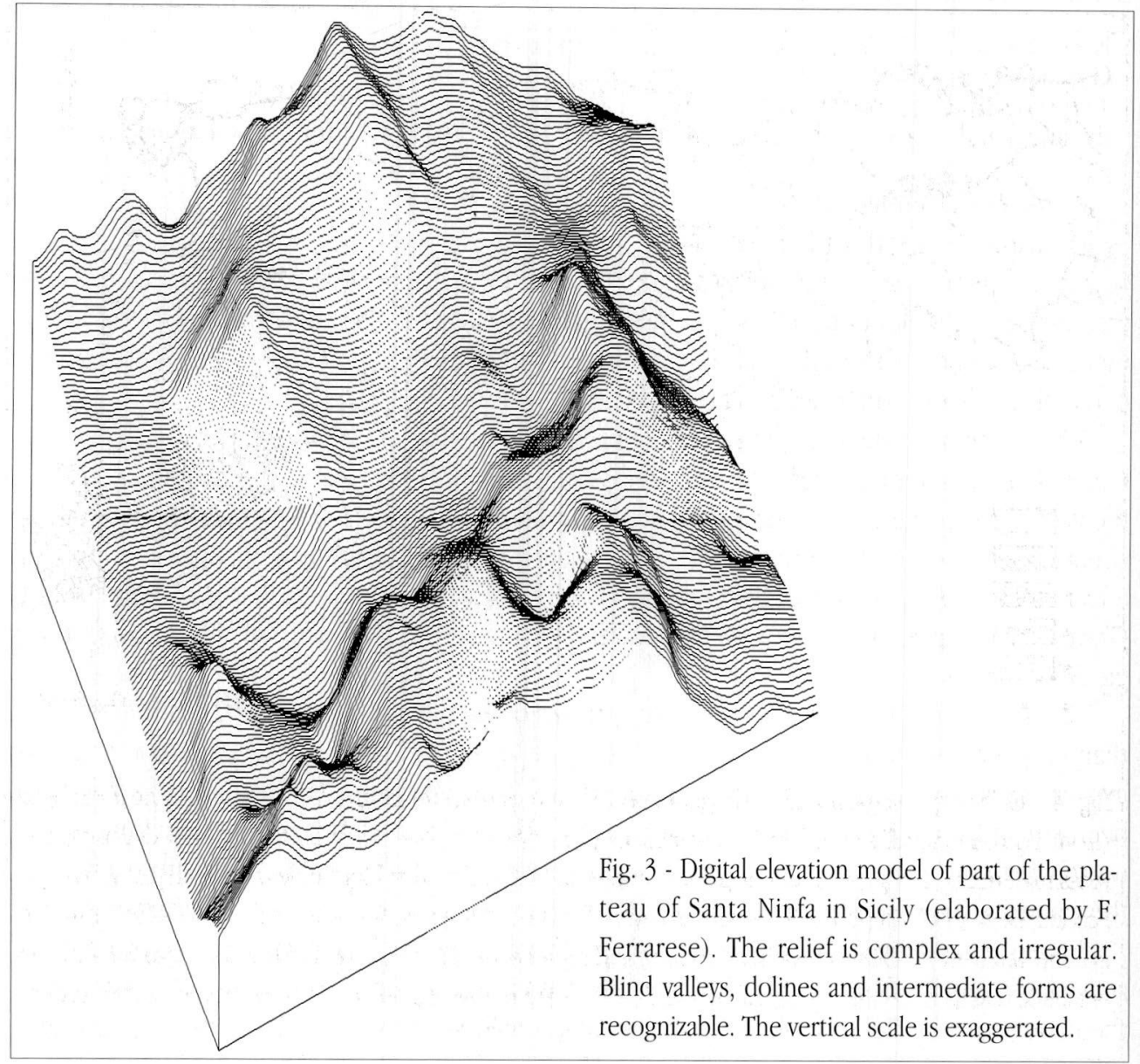


In some karst morpho-units, such as the Altopiano of Santa Ninfa in Sicily, transitional situations between subjacent karst, entrenched karst and denuded karst are found. From the morphological standpoint this is expressed by the co-existence of active valleys, dry valleys, blind valleys, doline chains and clusters of dolines that tend towards a honeycomb pattern. Each of these types can be correlated with a definite stage of cover rock erosion (Fig. 3).

Interesting examples of buried karst are present in some parts of Sicily (such as Serra Ciminna, Siculiana Mare), where permeable covers preserved above erosion surfaces cut in gypsum have favoured the development of an interface karst. Where later erosion exhumed this karst, unusual landscapes have developed, with deep clefts and trenches separating upstanding rocky features of stone forest and karren table type (Ruggeri \& Torre, 1987).

Buried and exhumed karst have both been described in the Vena del gesso. In particular, an erosion surface of late Messinian age has been buried and fossilized by the Formazione a Colombacci. A fossil terrestrial vertebrate fauna of late Messinian age has been found in the neptunian infillings of some palaeo-karst cavities (Costa et al, 1986).

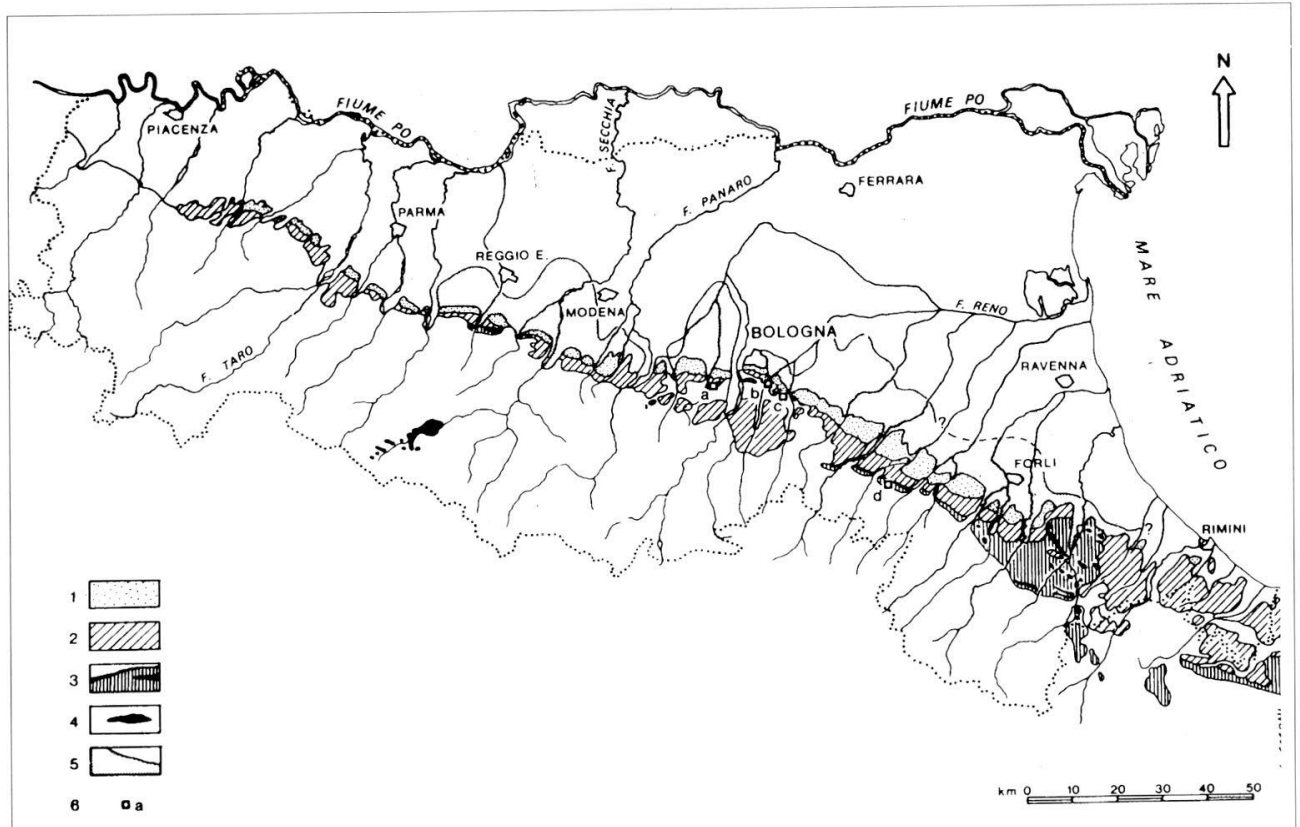

Fig. 4 - Geomorphological and hydrogeological sketch of a sector of the Vena del gesso near Bologna (from Forti, Francavilla et al, 1985): 1 = alluvial plain deposits; $2=$ valley bottom alluvial deposits; $3=$ Messinian marls; $4=$ gypsum outcrops; $5=$ undifferentiated clay; $6=$ blind valleys (A: Valley of Rio Acqua Fredda; B: Buca di Ronzano); $7=$ main dolines; $8=$ nested dolines; $9=$ main scarps; $10=$ main underground watersheds; $11=$ secondary underground watersheds; $12=$ direction of the underground flow; 13 $=$ karstic resurgences; 14 = permeable "dike"; $15=$ semi-permeable "dike"; $16=$ hydrogeological barrier. 
Considering this unconformity and its palaeokarst, the following hypothetical evolutionary model may be deduced for the sections with well developed karst landforms:

a) tectonic uplift and tilting of the surface, with development of a system of consequent valleys running down the dip and crossing the different rock units;

b) exhumation of the erosional palaeo-surface;

c) selective erosion, with favoured development of a bevelled cuesta type gypsum ridge, erosional valleys cutting water gaps in the ridge, and small dolines evolving on the ridge by re-activation of old karst features;

d) closure of some blind valleys developed inside the gypsum ridge; a retreat of sink points that develop sequentially at the upstream limit of the gypsum band, at the lithological contact between gypsum and clay formations;

e) the old depressions with sink points on the ridge evolve as large dolines.

Examination of the areas confirms that, as predicted, there are blind valleys that have cut through large crossing cave systems and big dolines with caves that also represent parts of old crossing systems (Fig. 4).

\section{Human impact and conservation}

The human impact upon the gypsum karst of Italy has been generally very strong since prehistoric times. Deforestation of the primary Mediterranean forest, the use of the land for agriculture and sheep or goat grazing has encouraged soil erosion and denudation of the rock on many slopes (Burri, 1989). The environmental fragility is greater in southern Italy, where, during the summer, there is a higher soil water deficit and vegetation is more susceptible to fires. Large areas of bare gypsum outcrop displaying exceptional weathering forms, especially karren, are now found in Sicily.

Quarrying is a more recent form of human impact. In the Vena del Gesso many large quarries have been opened since Roman times. Mediaeval towers in the town of Bologna were built with blocks of macro-crystalline gypsum. During this century larger quarries have been opened, leading to the destruction of some caves (Badini, 1967), and a famous cave system with many archaeological remains was damaged by quarrying (Varani, 1974).

In the gypsum karst of Moncenisio the construction of a dam caused a considerably enlargement of a natural lake. This resulted in activation of underground karstification, that was manifested at the surface as collapse phenomena.

Recent development activities in ski resort areas, particularly work on the construction of ski runs, has accelerated the denudation of some gypsum outcrops. At Cervinia, in the Aosta Valley, very rapid evolution of grikes and shafts has been observed, and on one occasion a sno-cat fell into a shaft.

In some valleys of the Southern Alps (for instance the Agordo valley) the increased urbanisation of certain areas, caused by the building of second homes, has triggered several instability and collapse phenomena due to the influence of deep-seated or buried gypsum karst.

In recent times natural reserves and parks devoted to gypsum karst have been established. 
The best known are the Parco dei gessi of Bologna, and the Riserva Naturale di Santa Ninfa in Sicily.

Research carried out according to the $40 \%$ and $60 \%$ programmes supported by M.U.R.ST (University and Scientific Research Governmental Agency), as 40\% Mountains and Plains: evolution of the relief in Italy and in the Mediterranean Region, human impact and morpho-dynamic processes in karst areas.

\section{REFERENCES}

AGNESI V., MACALUSO T., MENEGHEL M., SAURO U., (1989): Geomorfologia dell'area carsica di S. Ninfa (Sicilia occidentale), Memorie Istituto Italiano Speleologia, s. II, 3, Palermo, pp.: $23-48$.

BADINI G. (1967): L'opera di distruzione delle cave di gesso sul patrimonio speleologico bolognese, Natura e Montagna, 3, 7, (3), Bologna, pp.: 51-60.

BADINI G. (1967): Le grotte bolognesi, Rassegna Speleologica Italiana Ed. Divulgative R.S.I., Como, pp.: 1143 .

BERTOLANI M. ROSSI A. (1972a): La grotta Michele Gortani ai Gessi di Zola Predosa (Bologna), Rassegna Speleologica Italiana, Mem X, Como, pp.: 205-245.

BERTOLANI M. ROSSI A. (1972b): Osservazioni sui processi di formazione e di sviluppo della grotta del Farneto, Rassegna Speleologica Italiana, Memoria X, Como, pp.: 127-136.

BERTOLANI M. ROSSI A. (1972c): Osservazioni sull'affioramento gessoso di Gaibola (Bologna), Rassegna Speleologica Italiana, Memoria X., Como, pp.: 246-257.

BERTOLANI M., FORTI P., REGNOLI R. (1980): Il catasto delle cavita' naturali dell'Emilia-Romagna, Pitagora Ed., Bologna, pp.: 1-249.

BINI A., (1983): Appunti sul carsismo nei gessi della Formazione a Bellerophon al Passo di San Pellegrino Dolomiti (Italia), Atti Convegno Internazionale "Carsismo di Alta Montagna", Imperia 1982, 1, pp.: 33-36.

BURRI E. (1986): Various aspects of the karstic phenomenon in the urbanised area of Gissi and neighburing areas (Southern Abruzzo, Italy), Le Grotte d'Italia, s. 4, XII, Bologna, pp.: 143-159.

CAPELLO C.F. (1955): Il fenomeno carsico in Piemonte: le zone interne del sistema alpino, CNR-Ricerche di morfologia e idrologia carsica, 6, Roma, pp.: 1-140.

CASALI R., FORTI P., GNANI S. (1983): Guida ai gessi del Bolognese, Calderini Ed., Bologna, pp.: 182.

CHIESI M. (1989): Il carsimo nelle evaporiti triassiche toscoemiliane, Le Grotte d'Italia, s. 4, XIV, Bologna, pp.: 607-621.

COSTA G.P., COLALONGO M.L., DE GIULI C., MARABINI S., MASINI F., TORRE D., VAI G.B. (1986): Latest messinian vertebrate fauna preserved in a paleokarst neptunian dyke setting, Le Grotte d'Italia, s. 4, XII, Bologna, pp.: 221-235.

COSTA, Gian Paolo; FORTI, Paolo; BENTINI, Luciano (1994): Morfologia e carsismo. In: La Vena del Gesso. Edit. Regione Emilia - Romagna, Collana Naturalistica, Assessorato Programmazione Pianificazione e Ambiente, 431 pagg., dic. 1994: pag. 83-141.

DAINELLI G., (1907): Cavità di erosione nei gessi del Moncenisio, Mondo Sotterraneo, 3 (3-4), Udine, pp.: $55-68,113$

DESIO A. (ed.) (1973): Geologia dell'Italia. U.T.E.T., Torino, $1081 \mathrm{pp}$

FERRINI G. Ed. (1989): I gessi di Verzino (KR): Studio multidisciplinare di un'area carsica. Mem. 
dell'Istituto Italiano di Speleologia, 9, s.2, (in print).

FORTI O. \& GRIMANDI P. Eds, (1986): Atti del Simposio internazionale sul carsismo delle evaporiti. Bologna, 1985, Le Grotte d'Italia, s.4, v. 12, 420 pp.

FORTI P., AGNESI V., MACALUSO T., Eds, (1989): I gessi di Santa Ninfa (Trapani): Studio multidisciplinare di un'area carsica. Mem. dell'Istituto Italiano di Speleologia, 3, s.2, 202 pp.

FORTI P., AGNESI V., MACALUSO T., PANZICA LA MANNA M. Eds, (1987): Atti del Simposio internazionale sul carsismo delle evaporiti. Il carsismo delle evaporiti in Sicilia. Palermo, 1985, Le Grotte d'Italia, s.4, v. 13, 213 pp. FORTI P., FRANCAVILLA F. (1988): Hydrodynamics and hydrochemical evolution of gypsum karst aquifers: data from the Emilia Romagna Region, XXI Congress IAH, Guilin, Cina, vol. I, pp.: 219-224.

FORTI P., FRANCAVILLA F., PRATA E., RABBI E., VENERI P., FINOTELLI F. (1985): Evoluzione idrogeologica dei sistemi carsici dell' Emilia-Romagna: 1- Problematica generale; 2- Il complesso Spipola - Acqua Fredda". Regione Emilia Romagna, Tip. Moderna, Bologna, pp.: 1-60.

GORTANI M. (1965): Doline alluvionali in Carnia, Mondo Sotterraneo, Udine, pp.: 14-20.

GRUPPO SPELEOLOGICO EMILIANO, COMITATO SCIENTIFICO F. MALAVOLTI (1972): Studio della Grotta di fianco alla Chiesa di Gaibola (24 E) nei gessi delle colline bolognesi, Rassegna Speleologica Italiana, 24, (2), Como, pp.: 103-149.

GRUPPO SPELEOLOGICO EMILIANO, GRUPPO SPELEOLOGICO BOLOGNESE, SPELEOCLUB BOLOGNA, UNIONE SPELEOLOGICA BOLOGNESE, GRUPPO GROTTE F. ORSONI, (1966): Le cavità naturali dell'Emilia-Romagna. Parte II: le grotte del territorio gessoso tra i torrenti Zena e Olmatello (Provincia di Bologna), Rassegna Speleologica Italiana, 18,(1-2), Como, pp.: 23-59.

GRUPPO SPELEOLOGICO "SPARVIERE" (1994): Le Grotte dell'alto Crotonese, Grafica Mariani, Triggiano, Bari, 79 pp.

LAROCCA F. (1991): Le grotte della Calabria, Apulia Ed., Martina Franca, pp.: 1-222.

MACALUSO T. \& SAURO U. (1996) - The Karren in evaporitic rocks: a proposal of classification In: J. J. FORNOS \& A. GINES (Eds.) Karren Landforms, Universitat de les Illes Balears, Palma de Mallorca, 277-293. MARINELLI O. (1917): Fenomeni carsici nelle regioni gessose d'Italia, Materiali per lo studio sui Fenomeni. Carsici III, Memorie Geografia Suppl. Rivista Geografica Italiana 34, pp.: 263-416.

NICOD, Jean (1976): Karsts des gypses et des évaporites associées.- Annales de Géographie. n471: p.513554 .

PANZICA LA MANNA M. (1992): Fenomeni carsici e speleogenesi in Sicilia. Rivista Mineraria Siciliana, 162, 47-70. RUGGIERI C., TORRE G. (1987): Carsismo fossile sopramiocenico nei gessi messiniani di Ciminna (Palermo), Giornale di Geologia, 49, (3), Bologna, pp.: 81-88.

SAURO U. (1987): Lo stato attuale degli studi sul carsismo nelle evaporiti in Italia, Le Grotte d'Italia, s. 4, XIII, Bologna, pp.: 93-106.

TREVISAN L, DI NAPOLI E., (1937) - Tirreniano, Siciliano e Calabriano nella Sicilia sud-occidentale. Note di stratigrafia, Paleontologia e Morfologia. Giorn. Sc. Nat. e Econ. Palermo, 39/8, 1-37.

VARANI L. (1974): Evoluzione dei rapporti uomo-ambiente nei Gessi bolognesi e romagnoli, Bollettino Società Geografica Italiana, 9, 15, (7-12), Roma, pp.: 325-347. 